\title{
NORTHERN IRELAND
}

Feargal Cochrane is Emeritus Professor of International Conflict Analysis and Senior Research Fellow at the Conflict Analysis Research Centre, University of Kent. He is the author or co-author of eleven books, including Breaking Peace: Brexit and Northern Ireland, Mediating PowerSharing and Migration and Security in the Global Age. 

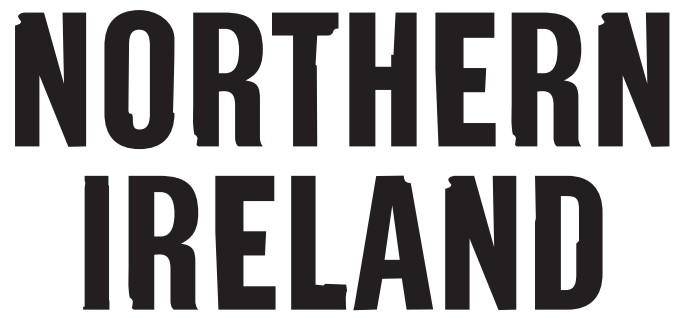

THE FRAGILE PEACE

\author{
NEW EDITION
}

FEARGAL COCHRANE 
Copyright () 2013 Feargal Cochrane

Chapters 10, 11 and Epilogue copyright (C) 2021 Feargal Cochrane

This new edition published in paperback in 2021

The right of Feargal Cochrane to be identified as author of this work has been asserted by him in accordance with the Copyright, Designs and Patents Act 1988.

Extracts on p. 119 from the poems 'Ulster Names' and 'Postscript 1984' by John Hewitt are taken from John Hewitt, The Selected Poems of Fohn Hewitt, ed. Michael Longley \& Frank Ormsby (Blackstaff Press, 2007) and reproduced by permission of Blackstaff Press on behalf of the Estate of John Hewitt.

All rights reserved. This book may not be reproduced in whole or in part, in any form (beyond that copying permitted by Sections 107 and 108 of the U.S. Copyright Law and except by reviewers for the public press) without written permission from the publishers.

For information about this and other Yale University Press publications, please contact:

U.S. Office: sales.press@yale.edu yalebooks.com

Europe Office: sales@yaleup.co.uk yalebooks.co.uk

Set in Janson Text by IDSUK (DataConnection) Ltd

Printed in Great Britain by Clays Ltd, Elcograf S.p.A

Library of Congress Control Number: 2020947087

ISBN 978-0-300-17870-8 (hbk)

ISBN 978-0-300-20552-7 (new edn pbk)

A catalogue record for this book is available from the British Library.

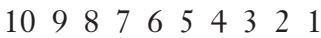


For Oisín

and

In memory of Lyra McKee 
